\title{
PERSEPSI RISIKO ATAS IMBAUAN SOCIAL DISTANCING AKIBAT PANDEMI COVID-19
}

\author{
Umar Yahya', Adnan Achiruddin Saleh²
}

\section{STAIDDI SIDRAP ${ }^{1}$, IAIN PAREPARE ${ }^{2}$}

\author{
umaryahya@gmail.com
}

$\underline{\text { Received : } 3 \text { June } 2021 \mid \text { Reviewed: } 17 \text { July } 2021 \mid \text { Accepted: } 1 \text { September } 2021}$

\begin{abstract}
ABSTRAK
Penelitian ini bertujuan untuk menggambarkan persepsi risiko masyarakat atas pandemi Covid-19 dan imbauan social distancing di Kabupaten Sidenreng Rappang (Sidrap), Sulawesi Selatan. Temuan penelitian diharapkan memberi rekomendasi gagasan kepada pemangku kepentingan. Penelitian ini menggunakan data berupa data primer dengan menyebarkan kuesioner secara online. Jumlah sampel mempertimbangkan jumlah perumahan sebagai populasi yaitu 5.989. Jumlah responden penelitian adalah 105. Teknik sampling adalah purposive sampling. Teknik analisis data adalah deskriptif kuantitatif, menggunakan program SPSS. Hasil penelitian menunjukkan dari keenam tipe persepsi risiko menunjukkan bahwa psychological risk (risiko psikologis) termasuk kategori sangat tinggi yakni $82.34 \%$, Physical risk (risiko fisik) termasuk kategori ting gi yakni $71.45 \%$, dan performance risk (risiko realitas informasi), finance risk (risiko keuangan), time-losss risk (risiko kehilangan waktu), social risk (risiko sosial) berada pada kategori sedang dengan masing-masing persentasi yakni 49.63\%, 57.29\%, $55.94 \%, 44.46 \%$. Data ini bisa dipahami bahwa semakin tinggi persentase berarti semakin tinggi persepsi risiko masyarakat dan begitupun sebaliknya.
\end{abstract}

Kata Kunci: Pandemi Covid-19, Persepsi Risiko, Social Distancing

\section{ABSTRACT}

This research aims to describe the community risk perception of the Covid-19 epidemic and social distancing in Sidenreng Rappang Distrct, South Sulawesi Selatan. Research findings are expected to provide recommendation to stakeholders. Thhis study uses data in the form of primary data by Korespondensi: distributing questionnaires online. The number of population is 5.989. The number of respondent is STAI DDI SIDRAP 1 , IAIN PAREPARE ${ }^{2}$

Jl. Tugu Tani, Danau Sijabut, Air Batu, Kabupaten Asahan, Sumatera Utara1, Kec. Soreang, KotajURNAL ILMIAH DINAMIKA SOSIAL 5 (2) 2021|59 Parepare, Sulawesi Selatan 91131 
105. The sampling technique used is quantitative describtive, using SPPS Program. The results showed that psychological risk included in the very high category that is $82.34 \%$, pgysical risk included in the hig category $71,45 \%$, and performance risk, finance risk, time-loss risk, social risk is in the medium category with each percentage ie; 49.63\%, 57.29\%, 55.94\%, 44.46\%. This data can be understood that the higher the percentage means the higher the community risk perception and vice versa.

Keywords: Covid-19 epidemic, Risk Perception, Social Distancing

\section{PENDAHULUAN}

Covid-19 telah menyita perhatian dunia terhitung sejak akhir tahun 2019 sampai saat ini Maret 2020. Covid-19 menjadi kekuatiran warga dunia karena kebaruan jenisnya yang belum pernah muncul dalam sejarah virus di dunia. Virus Corona telah dinyatakan sebagai pandemik oleh organisasi kesehatan dunia dengan melihat jumlah negara yang telah terdampak yaitu 185 dengan jumlah kasus 267.013 dan 11.201 telah dinyatakan meninggal dunia (https://www.who.int/emergencies/diseases/novel-coronavirus-2019) (diakses hari Minggu tanggal 22 Maret 2020 Pukul 22.15 WITA). Di Indonesia, jumlah kasus berjumlah 514 dimana 48 dinyatakan meninggal dunia (https://www.kemkes.go.id/) (diakses hari Minggu tanggal 22 Maret 2020 Pukul 22.30 WITA). Di Propinsi Sulawesi Selatan, data yang diaksek https://covid19.sulselprov.go.id/ (Hari Minggu tanggal 22 Maret 2020 Pukul 22.45) menunjukkan bahwa jumlah kasus positif berujumlah 2 orang di mana terdapat Orang Dalam Pemantauan (ODP) berjumlah 108, Pasien Dalam Pengawasan (PDP) berjumlah 28. Di Kabupaten Sidenreng Rappang, terdapat 2 Pasien Dalam Pengawasan dan 1 Orang Dalam Pemantauan.

Pemerintah Indonesia melalui Presiden Republik Indonesia mengeluarkan kebijakan berupa social distancing. Pemerintah Propinsi Sulawesi Selatan juga bergerak dengan mengeluarkan kebijakan oleh Gubernur propinsi Sulawesi Selatan. Selain itu, fatwa dikeluarkan juga oleh Majelis Ulama Indonesia Sulawesi Selatan agar bisa menjaga jarak dengan orang lain meskipun dalam kegiatan keagamaan. Kebijakan ini diharapkan mampu membatasi aktifitas bersama orang lain secara massif serta menghindari kerumunan dalam durasi yang lama.

Kebijakan telah dikeluarkan oleh Pemerintah (pusat dan daerah) dan penyebaran informasi yang massif melalui media. Namun, masih banyak masyarakat Sulawesi Selatan khususnya di Kabupaten Sidenreng Rappang yang masih setengah hati dalam melaksanakan social distancing. Masyarakat masih kurang percaya social distancing akan membawa manfaat.

Hasil penelitian dari Timothy C. Reluga menunjukkan bahwa social distancing paling bermanfaat bagi individu dengan lainnya dengan jarak dua meter. Praktik social distancing dipercaya dapat mengurangi tingkat keparahan penyebaran pandemi. Akan tetapi manfaat social distancing tergantung pada sejauh mana seseorang mampu melakukan dengan mengorbankan kebiasaan yang selama dilakukan.

Tantangan penerapan social distancing bukanlah tidak ditemukan. Dua objek yang sama bisa disikapi berbeda oleh orang yang berbeda. Cara pandang orang terhadap social distancing apakah berisiko atau tidak berisiko yang mempengaruhi bagaimana seseorang 
mempersepsikannya. Slovic (2000) mengungkapkan bahwa cara orang memandang risiko bersifat subjektif. Risiko tidak terlepas dari pikiran dan budaya. Konsep risiko adalah membantu orang memahami dan mengatasi bahaya dan ketidakpastian dalam hidup. Meskipun bahaya-bahaya itu nyata, tetapi tidak ada yang namanya risiko nyata atau risiko objektif.

Persepsi risiko muncul dari tipe potensi kerugian yang berbeda-beda (Hoyer, MacInnis, dan Pieters, 2013). Ada 6 tipe potensi kerugian yang kemudian menjadi sebuah risiko, yaitu physical risk (adanya risiko yang mengancam kondisi fisik atau keamanan masyarakat), performance risk (risiko yang berkaitan dengan kinerja atau informasi atau layanan yang diberikan oleh pemerintah Indonesia yang tidak sesuai dengan harapan masyarakat), psychological risk (risiko munculnya emosi negatif terhadap pandemi Covid-19), financial risk (adanya risiko kerugian finansial oleh masyarakat akibat pandemi Covid-19), time-loss risk (adanya risiko waktu yang terbuang percuma atas imbauan social distancing akibat pandemi Covid-19), dan social risk (risiko akibat kurang atau tidak berinteraksi dengan orang lain atau lingkungan).

Persepsi seseorang terhadap risiko tersebut yang bersifat subjektivitas berakibat pada masalah yang kita hadapi bisa lebih sederhana pada satu sisi, namun akan lebih kompleks pada sisi lain. Saat angka pasien terjangkit Covid-19 semakin bertambah dengan cepat, Pemerintah Indonesia mempersepsi bahwa ini harus bisa dikendalikan dengan membatasi aktivitas masyarakat melalui imbauan social distancing dalam praktiknya yaitu sekolah diliburkan 2 minggu, bekerja dari rumah, dan beribadah di rumah. Namun, tidak semua masyarakat punya persepsi yang sama dengan pemerintah atas imbauan tersebut. Padahal untuk menghadapi pandemi butuh persepsi yang sama terhadap risiko sehingga kebijakan, keputusan, dan program bisa lebih optimal. Pandemi tidak bisa dihentikan jika ada yang memandang virus ini berbahaya dan melakukan upaya pencegahan namun ada sebagian masyarakat yang tidak memandang berbahaya sehingga melakukan aktivitas yang justru menambah laju pandemi.

Penelitian terkait persepsi risiko bisa dilihat melalui hasil penelitian Melissa Gunawan, dkk yang bertujuan menganalisa pengaruh persepsi risiko guest terhadap keputusan pembeliannya di Airbnb. Hasil penelitian menunjukkan bahwa dari keenam dimensi persepsi risiko yang ada, hanya social risk yang berpengaruh secara positif dan signifikan terhadap keputusan pembelian di Airbnb. Physical risk, performance risk, psychological risk, financial risk, dan time-loss risk memiliki hubungan yang searah dengan keputusan pembelian di Airbnb.

Penelitian lainnya terkait dengan persepsi risiko bisa dilihat dari temuan Scherer (2003) yang menunjukkan bahwa persepsi risiko yang merupakan proses dalam diri individu dalam mengumpulkan, memproses, dan membentuk persepsi yang dipengaruhi oleh hubungan individu di masyarakat (sosial) dan berperan penting dalam memfokuskan persepsi terhadap risiko tertentu.

Penelitian Djalante, dkk (2020) menunjukkan terdapat lima rekomendasi untuk tanggapan yang lebih cepat, efektif, dan komprehensif kepada pemerintah. Kelima rekomendasi tersebut adalah pertama yakni memperkuat respon kesehatan seperti yang digariskan oleh WHO, kedua yakni pro aktif dengan memperkuat koordinasi bencana kemanusiaan dan pengambilan keputusan pada level pemerintah daerah selama krisis dan situasi darurat, ketiga yakni memperkuat ketahanan ekonomi, keempat yakni pengambilan 
keputusan mengedepankan multi disiplin dan memastikan transparansi serta komunikasi strategi krisis dan risiko dengan melibatkan inluencer sosial terutama untuk melakukan isolasi diri dan tindakan preventif kesehatan, kelima yakni mempromosikan pendekatan inklusif dan berbasis masyarakat untuk ketahanan dan kesiapan kesehatan masyarakat.

Olehnya itu, penelitian ini akan mampu menjadi bagian dari kajian atas usaha pengambilan keputusan oleh pemerintah daerah. Penelitian ini hadir untuk memetakan persepsi risiko yang ada di masyarakat dan temuannya akan menjadi kajian bagi pemangku kepentingan (Pemda dan Kemenag Sidrap) dalam merumuskan kebijakan, keputusan, dan program sebagai upaya mengoptimalkan imbauan social distancing.

\section{METODE}

Penelitian ini merupakan penelitian deskriptif. Dengan menggunakan metode deskriptif kuantitatif dan teknik pengumpulan datanya dengan angket tertutup. Populasi penelitian terdiri dari 5.989, dengan menggunakan formula Slovins didapatkan sampel berjumlah 105 responden di mana pemilihannya menggunakan teknik purposive sample dan menggunakan tingkat kepercayaan 90\%. Subjek penelitian berusia 18 tahun - 50 tahun yang berdomisili di Kabupaten Sidenreng Rappang.

Kuesioner dibuat berdasarkan skala likert lima poin alternatif jawaban. Kuesioner dikembangkan berdasarkan indikator variabel persepsi risiko, yaitu physical risk, Performance risk, Psychological risk, Financial risk, dan Time-loss risk. Pernyataan kuesioner dibagi menjadi dua jenis yakni favourabel (pernyatan positif) dan unfavorable (pernyataan negatif). Pada setiap alternatif jawaban diberi bobot nilai seperti pada tabel berikut ini (Riduwan, 2011):

Tabel 1

Bobot Nilai Jawaban Responden

\begin{tabular}{|l|l|l|l|}
\hline \multirow{2}{*}{ No. } & \multirow{2}{*}{ Jawaban Responden } & \multicolumn{2}{c|}{ Skor } \\
\cline { 3 - 4 } & & Positif & Negatif \\
\hline 1 & Sangat Setuju & 5 & 1 \\
\hline 2 & Setuju & 4 & 2 \\
\hline 3 & Netral & 3 & 3 \\
\hline 4 & Tidak Setuju & 2 & 4 \\
\hline 5 & Sangat Tidak Setuju & 1 & 5 \\
\hline
\end{tabular}

Tabulasi data dan pengolahan data dilaksanakan dengan cara yaitu memberi skor pada setiap item pernyataan, menjumlahkan skor pada pada setiap item, menghitung rata-rata setiap item dan variabel, menghitung Tingkat Capaian Responden (TCR) tiap item, dan menyusun rangking skor pada setiap variabel.

Untuk menghitung TCR dilakukan dengan cara (Riduwan, 2011):

a. Pernyatan positif

a. Skor setiap item dihitung dengan cara: 
Bobot $1 \mathrm{X} \sum$ responden yang menjawab sangat tidak setuju=

Bobot $2 X \sum$ responden yang menjawab tidak setuju $\quad=\ldots \ldots \ldots \ldots$

Bobot $3 \times \sum$ responden yang menjawab netral $\quad=\ldots \ldots \ldots \ldots$

Bobot $4 X \sum$ responden yang menjawab setuju $\quad=\ldots \ldots \ldots \ldots$

Bobot $5 \mathrm{X} \sum$ responden yang menjawab sangat setuju $=\ldots \ldots \ldots \ldots+$

Skor item yang dihitung

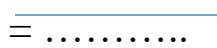

b. Menghitung TCR dengan cara:

$$
\mathrm{TCR}=\frac{\text { Skor tiap item }}{\text { Skor ideal item yang dihitung }} \mathrm{X} 100 \%
$$

b. Pernyataan negatif

a. Skor setiap item dihitung dengan cara:

Bobot $1 \mathrm{X} \sum$ responden yang menjawab sangat setuju $=$

Bobot $2 \times \sum$ responden yang menjawab setuju $=$

Bobot $3 \times \sum$ responden yang menjawab netral $=\ldots \ldots \ldots$.

Bobot $4 X \sum$ responden yang menjawab tidak setuju $\quad=\ldots \ldots \ldots \ldots$

Bobot $5 \mathrm{X} \sum$ responden yang menjawab sangat tidak setuju $=\ldots \ldots \ldots \ldots+$

Skor item yang dihitung

b. Menghitung TCR dengan cara:

$$
\mathrm{TCR}=\frac{\text { Skor tiap item }}{\text { Skor ideal item yang dihitung }} \times 100 \%
$$

c. Cara menghitung skor ideal tiap item adalah Skor Ideal $=5$ X Jumlah Responden

d. Cara menentukan kriteria interpretasi skor sebagai berikut:
Skor $81 \%-100 \%$
Sangat Tinggi
Skor $61 \%-80 \% \quad$ Tinggi
Skor $41 \%-60 \% \quad$ Sedang
Skor $21 \%-40 \% \quad$ Rendah
Skor $0 \%-20 \% \quad$ Sangat Rendah

\section{HASIL}

Persepsi risiko adalah ketidakpastian yang dihadapi oleh masyarakat ketika tidak dapat memprediksi konsekuensi saat melakukan keputusan social distancing. Terdapat dua poin penting dalam pemaknaan ini yakni ketidakpastian dan konsekuensi. Hal ini dapat dipahami bahwa masyarakat dipengaruhi oleh risiko yang dipersepsikan tanpa mempedulikan apakah sebenarnya risiko itu ada atau tidak. Risiko yang tidak ada dalam persepsi masyarakat tidak akan mempengaruhi perilaku masyarakat dalam mengambil keputusan (Schiffman dan Kanuk, 2010). Demikian juga dengan pendapat Hoyer, Maclnnis, dan Pieter (2013), mengungkapkan bahwa terdapat enam tipe risiko yang dipersepsikan oleh masyarakat yaitu:

1. Physical risk: yaitu adanya risiko yang mengancam kondisi fisik atau keamanan terhadap penyebaran Covid-19 saat melakukan social distancing. Yeung (2009) didukung oleh Aslan, Geçti, dan Zengin (2013) menggunakan indikator kemungkinan menjadi sakit dan menderita ketidaknyamanan ketika keluar rumah atau berdekatan dengan orang lain akibat penularan covid-19. 
Tabel 2

Variabel Physical Risk

\begin{tabular}{|c|c|c|c|c|c|c|c|c|c|}
\hline \multicolumn{10}{|c|}{ Statistics } \\
\hline & & A11 & A12 & A13 & A14 & A15 & A16 & A17 & TotalA \\
\hline \multirow[t]{2}{*}{$\mathrm{N}$} & Valid & 105 & 105 & 105 & 105 & 105 & 105 & 105 & 105 \\
\hline & Missing & 0 & 0 & 0 & 0 & 0 & 0 & 0 & 0 \\
\hline \multicolumn{2}{|c|}{ Mean } & 2.81 & 3.05 & 3.88 & 4.10 & 3.82 & 3.38 & 2.78 & 23.82 \\
\hline \multicolumn{2}{|c|}{ Median } & 3.00 & 3.00 & 4.00 & 4.00 & 4.00 & 4.00 & 3.00 & 24.00 \\
\hline \multicolumn{2}{|c|}{ Mode } & 3 & 4 & 4 & 5 & 4 & 4 & 2 & $21^{\mathrm{a}}$ \\
\hline \multicolumn{2}{|c|}{ Sum } & 295 & 320 & 407 & 431 & 401 & 355 & 292 & 2501 \\
\hline
\end{tabular}

a. Multiple modes exist. The smallest value is shown

Tingkat Capaian Responden (TCR) secara total (7 item) adalah 71.45\%. Ini berarti termasuk dalam kategori tinggi. Berdasarkan temuan ini dapat dipahami bahwa masyarakat memiliki persepsi terhadap dampak risiko fisik pada tubuhnya akibat penyebaran Covid-19. Hal ini dapat diketahui dari temuan bahwa masyarakat mempersepsikan bahwa bagian tubuh akan rentan terhadap penyebaran virus Corona.

Temuan ini menarik untuk didalami bahwa penguatan kampanye social distancing akan optimal apabila materi yang diberikan mengutamakan pada bahayanya bagi tubuh saat berada di luar rumah. Pemberian informasi terkait bahayanya virus Corona padabagian tubuh dan menjadi bagian yang paling menjadi penyebab penularan virus akan menguatkan komitmen masyarakat dalam melakukan social distancing.

2. Performance risk yaitu risiko yang berkaitan dengan realita informasi dari pemerintah terkait jenis dan data penyebaran covid-19 yang tidak sesuai dengan harapan masyarakat. Maciejewski (2012) menggunakan indikator kualitas pelayanan informasi yang kurang baik terbuka dan kurang puas terhadap kualitas informasi yang ada.

Tabel 3

Variabel Performance Risk

\begin{tabular}{|c|c|c|c|c|c|c|c|c|}
\hline \multicolumn{9}{|c|}{ Statistics } \\
\hline & & B11 & B12 & B13 & B14 & B15 & B16 & ToralB \\
\hline \multirow[t]{2}{*}{$\mathrm{N}$} & Valid & 105 & 105 & 105 & 105 & 105 & 105 & 105 \\
\hline & Missing & 0 & 0 & 0 & 0 & 0 & 0 & 0 \\
\hline \multicolumn{2}{|c|}{ Mean } & 2.31 & 2.74 & 2.62 & 2.22 & 1.90 & 2.39 & 14.18 \\
\hline \multicolumn{2}{|c|}{ Median } & 2.00 & 2.00 & 2.00 & 2.00 & 2.00 & 2.00 & 14.00 \\
\hline \multicolumn{2}{|c|}{ Mode } & 2 & 2 & 2 & 2 & 2 & 2 & 12 \\
\hline \multicolumn{2}{|c|}{ Sum } & 243 & 288 & 275 & 233 & 199 & 251 & 1489 \\
\hline
\end{tabular}

Tingkat Capaian Responden (TCR) secara total (6 aitem) adalah 49.63\%, berarti termasuk dalam kategori sedang. Berdasarkan temuan ini dapat dipahami bahwa masyarakat cukup meletakkan proporsional informasi yang disampaikan oleh 
pemerintah sebagai risiko. Hal ini berarti bahwa masyarakat masih percaya terhadap informasi yang dibagikan oleh masyarakat lainnya melalui media sosial dan pemerintah sebagai pemangku kepentingan utama.

Temuan ini seharusnya dapat dimanfaatkan oleh pemerintah agar bisa memberikan informasi terkait penyebaran virus Corona secara lebih massif lagi. Temuan ini juga mengindikasikan bahwa masyarakat termasuk mudah percaya informasi yang disampaikan atau dibagikan oleh masyarakat lainnya di media sosial yang belum tentu terkonfirmasi benar.

3. Psychological risk yaitu risiko munculnya emosi negatif yang mempengaruhi keadaan mental seseorang. Yeung (2009) menggunakan indikator kemungkinan merasa stress dan kuatir akibat risiko keselamatan yang mungkin menimpa masyarakat.

\section{Tabel 4}

Variabel Psychological Risk

\begin{tabular}{|c|c|c|c|c|c|c|c|c|c|}
\hline \multicolumn{10}{|c|}{ Statistics } \\
\hline & & C11 & $\mathrm{C} 12$ & $\mathrm{C} 13$ & C14 & $\mathrm{C} 15$ & $\mathrm{C} 16$ & C17 & TotalC \\
\hline \multirow[t]{2}{*}{$\mathrm{N}$} & Valid & 105 & 105 & 105 & 105 & 105 & 105 & 105 & 105 \\
\hline & Missing & 0 & 0 & 0 & 0 & 0 & 0 & 0 & 0 \\
\hline \multicolumn{2}{|c|}{ Mean } & 4.42 & 3.15 & 3.83 & 3.88 & 3.95 & 4.12 & 4.10 & 27.45 \\
\hline \multicolumn{2}{|c|}{ Median } & 4.00 & 3.00 & 4.00 & 4.00 & 4.00 & 4.00 & 4.00 & 27.00 \\
\hline \multicolumn{2}{|c|}{ Mode } & 5 & 3 & 4 & 4 & 4 & 4 & 4 & 26 \\
\hline \multicolumn{2}{|c|}{ Sum } & 464 & 331 & 402 & 407 & 415 & 433 & 430 & 2882 \\
\hline
\end{tabular}

Tingkat Capaian Responden (TCR) secara total (7 aitem) adalah 82.34\% ini berarti termasuk dalam kategori sangat tinggi. Berdasarkan temuan diatas dapat dipahami bahwa masyarakat memiliki emosi negatif yang tinggi akibat penyebaran Covid-19 ini. Masyarakat merasa terlalu kuatir akan penularan virus Corona dan dampak dari imbauan social distancing. Hal ini berdampak pada sikap kepanikan masyarakat, salah satunya adalah buying panic, yang berimbas pada langkanya barangbarang tertentu yang sangat diperlukan dalam penanganan penyebaran virus Corona ini.

Temuan ini seharusnya menjadi konsen dari Pemerintah Daerah termasuk Kementerian Agama dan pemangku kepentingan terkait agar bisa mengambil keputusan dan program yang mengedepankan materi kesehatan mental atau psikologis masyarakat. Pemerintah memiliki instrumen pelaksana yang sangat bisa melakukan. Salah satu yang bisa dimanfaatkan adalah Penyuluh Agama dibawah koordinir Kementerian Agama untuk memberi penyuluhan-penyuluhan kepada masyarakat agar tetap tenang dan tidak panik, namun tetap waspada dengan mengindahkan imbauan social distancing.

4. Financial risk yaitu risiko adanya kerugian finansial atas akibat penyebaran virus Corona dan imbauan social distancing. Tidak mampu mendapatkan tambahan atau bahkan mengurangi pendapatan. 
Tabel 5

Variabel Financial Risk

\begin{tabular}{|l|r|r|r|r|r|r|r|r|}
\hline & D11 & D12 & D13 & D14 & D15 & D16 & D17 & TotalD \\
\hline N Valid & 105 & 105 & 105 & 105 & 105 & 105 & 105 & 105 \\
$\quad$ Missing & 0 & 0 & 0 & 0 & 0 & 0 & 0 & 0 \\
Mean & 2.87 & 2.92 & 2.50 & 2.74 & 2.79 & 2.64 & 2.64 & 19.10 \\
Median & 3.00 & 3.00 & 2.00 & 3.00 & 3.00 & 3.00 & 3.00 & 20.00 \\
Mode & 2 & 3 & 2 & 2 & 3 & 3 & 3 & 21 \\
Sum & 301 & 307 & 262 & 288 & 293 & 277 & 277 & 2005 \\
\hline
\end{tabular}

Tingkat Capaian Responden (TCR) secara total (7 aitem) adalah 57.29\% ini berarti termasuk dalam kategori sedang. Berdasarkan temuan tersebut dapat dipahami bahwa masyarakat memiliki persepsi atas risiko finansial akibat penyebaran virus Corona dan imbauan social distancing. Masyarakat menganggap dengan tidak melakukan aktivitas diluar rumah akan mempengaruhi kondisi ekonomi. Risiko yang dipersepsikan masyarakat terkait pendapatan berkurang atau tidak berpendapatan dengan imbauan social distancing ini.

Temuan ini sebaiknya mendapatkan respon cepat dari Pemerintah Daerah agar mempertimbangkan dampak dari pendapatan masyarakat atas kasus penyebaran Corona dan imbauan social distancing. Kekuatiran masyarakat tentu sangat beralasan baik dari golongan pengusaha kecil, besar, pegawai swasta, maupun Pengawai Negeri Sipil (Honor dan atau tunjangan).

5. Time-loss risk yaitu risiko adanya waktu yang terbuang percuma akibat proses social distancing. Jalilvand dan Samiei (2012) membagi variabel time-loss risk yaitu kemungkinan penundaan pekerjaan dan akan terjadi penumpukan. Sedangkan Yeung (2009) menggunakan indikator kemungkinan waktu dan usaha yang harus dikeluarkan dalam membeli kembali dan waktu yang hilang.

Tabel 6

Variabel Time-Loss Risk

\begin{tabular}{|c|c|c|c|c|c|c|c|c|c|}
\hline \multicolumn{10}{|c|}{ Statistics } \\
\hline & & E11 & E12 & E13 & E14 & E15 & E16 & E17 & TotalE \\
\hline \multirow[t]{2}{*}{$\mathrm{N}$} & Valid & 105 & 105 & 105 & 105 & 105 & 105 & 105 & 105 \\
\hline & Missing & 0 & 0 & 0 & 0 & 0 & 0 & 0 & 0 \\
\hline \multicolumn{2}{|c|}{ Mean } & 2.83 & 3.01 & 2.58 & 3.02 & 2.43 & 2.27 & 2.51 & 18.65 \\
\hline \multicolumn{2}{|c|}{ Median } & 3.00 & 3.00 & 2.00 & 3.00 & 2.00 & 2.00 & 2.00 & 19.00 \\
\hline \multicolumn{2}{|c|}{ Mode } & 2 & 3 & 2 & 3 & 2 & 2 & 2 & 21 \\
\hline \multicolumn{2}{|c|}{ Sum } & 297 & 316 & 271 & 317 & 255 & 238 & 264 & 1958 \\
\hline
\end{tabular}


Tingkat Capaian Responden (TCR) secara total (7 aitem) adalah 55.94\% ini berarti termasuk dalam kategori sedang. Berdasarkan temuan tersebut dapat dipahami bahwa masyarakat memiliki persepsi atas risiko kehilangan waktu dengan adanya imbauan social distancing. Masyarakat menganggap dengan hanya tinggal dirumah, ada banyak kesempatan yang terbuang utamanya dalam hal pekerjaan yang biasanya dilakukan di kantor atau di lapangan. Kebiasaan bekerja di kantor dirasa berbeda dan berdampak pada penumpukan pekerjaan ketika berada di rumah meskipun sedang imbauan Work From Home.

Temuan ini mengindikasikan bahwa upaya masyarakat dalam memanfaatkan waktu efektif dan efesien sangat dibutuhkan. Pemangku kepentingan terkait seharusnya menangkap kekuatiran ini sehingga mampu menguatkan pengelolaan waktu dan kegiatan yang optimal selama masa social distancing

6. Social risk adalah risiko akibat tidak berinteraksi sosial dengan orang lain sehingga akan mengancam persaudaraan atau persahabatan atau hubungan sosial. Risiko dipandang rendah oleh orang lain karena tidak akan menjaga interaksi

Tabel 7

Variabel Social Risk

\begin{tabular}{|c|c|c|c|c|c|c|c|c|}
\hline \multicolumn{9}{|c|}{ Statistics } \\
\hline & & $\mathrm{F} 11$ & $\mathrm{~F} 12$ & $\mathrm{~F} 13$ & F14 & F15 & $\mathrm{F} 16$ & TotalF \\
\hline \multirow[t]{2}{*}{$\mathrm{N}$} & Valid & 105 & 105 & 105 & 105 & 105 & 105 & 105 \\
\hline & Missing & 0 & 0 & 0 & 0 & 0 & 0 & 0 \\
\hline \multicolumn{2}{|c|}{ Mean } & 2.40 & 2.24 & 2.08 & 2.10 & 1.98 & 1.90 & 12.70 \\
\hline \multicolumn{2}{|c|}{ Median } & 2.00 & 2.00 & 2.00 & 2.00 & 2.00 & 2.00 & 12.00 \\
\hline \multicolumn{2}{|c|}{ Mode } & 2 & 2 & 2 & 2 & 2 & 2 & 12 \\
\hline \multicolumn{2}{|c|}{ Sum } & 252 & 235 & 218 & 221 & 208 & 200 & 1334 \\
\hline
\end{tabular}

Tingkat Capaian Responden (TCR) secara total (6 aitem) adalah 44.46\% ini berarti termasuk dalam kategori sedang. Berdasarkan temuan tersebut dapat dipahami bahwa masyarakat memiliki persepsi atas risiko sosial yang diakibatkan oleh penyebaran virus Corona dan imbauan social distancing. Masyarakat menganggap bahwa dengan tidak keluar rumah dan menjaga jarak dengan orang lain (termasuk keluarga) akan mengancam hubungan dan interkasi sosialnya. Sebagai masyarakat Bugis yang mengedepankan perilaku gotong royong dalam berbagai aspek dianggap akan terkikis dengan himbaun ini. Namun demikian, persentasi pada variabel ini mendekati kategori rendah, sehingga dapat pula dimaknai bahwa ada peluang masyarakat masih mampu memahami interaksi yang kurang.

Temuan ini akan lebih menarik apabila dilihat pada wilayah optimisme masyarakat akan tetap menjaga kekerabatan meskipun dalam masa social distancing. Peran pemangku kepentingan untuk tetap mengedepankan optimisme kepada 
masyarakat bahwa penyebaran virus Corona dan menjaga jarak dengan kerabat harus tetap terjaga. Meskipun jabat tangan dihindari namun "jabat hati” harus tetap erat.

\section{PEMBAHASAN}

Temuan menarik dari penelitian ini adalah tingkat persepsi risiko padarisiko psikologis yang sangat tinggi. Masyarakat merasakan stres atau kekuatiran atas adanya penyebaran virus Corona dan imbauan untuk menjaga jarak dengan orang lain. Stress muncul karena beragam konsekuensi yang masyarakat pikirkan yang belum tentu akan terjadi. Pada kondisi seperti ini maka yang paling baik dilakukan oleh masyarakat adalah regulasi diri, yakni suatu upaya mengendalikan pikiran, perasaan, dan perilaku dalam rangka mencapai tujuan (Rahman, 2014). Pemahaman ini bisa dimaknai bahwa terdapat tiga aspek yang harus dikendalikan, yakni pikiran, perasaan, dan perilaku. Galang (2019) menyebutkan bahwa pentingnya melakukan penyesuaian tingkat kesulitan tugas terhadap kapasitas maksimal masing-masing individu untuk menghasilkan efek stress. Penyesuaian pola kebiasaan yang baru baik bentuk tugas maupun strategi menyelesaikan tugas membutuhkan pertimbangan kapasitas individu.

Pemangku kepentingan meletakkan social distancing sebagai tujuan yang harus dipatuhi oleh masyarakat. Selain menyampaikan tujuan, seharusnya diikuti juga strategi yang mampu membantu masyarakat dalam mengontrol pikiran, perasaan, dan perilaku menjaga jarak dengan orang lain. Potensi masyarakat Bugis yang kental dengan perilaku sakral keagamaan seharusnya bisa dijadikan sebagai kekuatan dalam mencapai tujuan tersebut. Cunningham (2014) menegaskan bahwa terdapat hubungan yang erat antara konsep agama atau spiritualitas yang dapat diintegrasikan satu sama lain. Konsep spiritualitas berpengaruh pada risiko stress atau kesehatan kerja. McCullough dan Willoughby (2009) menemukan bahwa terdapat banyak ritual keagamaan yang mengajarkan regulasi diri terutama membentuk behavioral self regulation, yakni salah satu aspek perilaku dari konstruksi regulasi diri. Masyarakat Bugis Sidenreng Rappang yang Islami memungkinkan diberikan penguatan pada variabel ini, misalnya nilai kebersihan (mencuci tangan dan membaca doa sebelum makan, apabila bersin menutup mulut, hidung dan mengucapkan hamdalah, berwudhu sebelum tidur, dan lainnya). Pemangku kepentingan yang sangat memungkinkan melakukan ini adalah Kementerian Agama melalui penyuluh agama.

Selain kekuatiran terhadap dampak psikologis, masyarakat juga berpersepsi akan adanya risiko pada bagian tubuh yang bisa saja menjadi sumber penularan dan merusak fungsi tubuh tertentu. Masyarakat memperhatikan bahwa cara penularan Corona yang berbeda dari penyakit lainnya membuat adanya ketidakpastian pola komunikasi dengan orang lain. Sebagaimana ditegaskan oleh Yan Bai, dkk (2020) menjelaskan bahwa penularan Covid-19 melalui sentuhan tubuh dari orang ke orang. Tingginya persepsi risiko yang dialami masyarakat bisa dipahami karena kebiasaan masyarakat yang mud ah bergaul harus diganti dengan perilaku menjaga jarak dengan orang lain bahkan kerabat.

Roger menyebut realitas ini dengan istilah difusi inovasi, yakni proses untuk mengurangi ketidakpastian sebab merupakan rintangan utama bagi individu dan sistem sosial untuk berubah (Buddy, 2006). Agar masyarakat dapat merubah kebiasaan menjadi perilaku social distancing, maka dapat dilakukan melalui empat elemen (Buddy, 2006) yakni pertama inovasi (memastikan gagasan dengan baik), kedua saluran komunikasi (saluran bisa menggunakan media sosial dan interpersonal), ketiga waktu (memastikan proses pengambilan keputusan yang tepat bagi masyarakat saat menyampaikan inovasi), dan keempat sistem sosial 
(membentuk dan atau menguatkan kelompok sosial yang ada). Olehnya itu, peran pemerintah seharusnya dapat membentuk social distancing dengan menguatkan pada variabel ini. Perhatian masyarakat pada bagian tubuh ini memungkinkan pemangku kepentingan agar mendesain materi penyampaian informasi mengedepankan kepentingan menjaga bagian tubuh. Pemangku kepentingan yang sangat memungkinkan melakukan ini adalah dinas kesehatan.

Perhatian pemerintah dalam menyampaikan perkembangan kasus akan sangat dibutuhkan oleh masyarakat. Menurut Nuning Nuraini, dkk (2020) menegaskan bahwa proyeksi jumlah kasus di Indonesia secara konsisten meningkat hingga mencapai angka kasus lebih dari 8.000 kasus. Selain itu, jumlah kasus baru harian juga akan meningkat hingga akhir Bulan Maret, 2020, dengan angka maksimum jumlah kasus baru diperkirakan mencapai 600 kasus. Asumsi ini bila dilakukan social distancing yang ketat sehingga bisa dibayangkan bila langkah pencegahan ini tidak dilakukan secara serius, maka kasus bisa berlipat dalam puluhan, ratusan, ribuan bahkan jutaan penderita.

Prediksi kasus yang tinggi ini akan membuat perilaku sosial yang memang akan sulit diprediksi. Clifford W. Scherer (2003) menunjukkan bahwa persepsi risiko merupakan proses dalam diri individu dalam mengumpulkan, memproses, dan membentuk persepsi dipengaruhi oleh hubungan individu di masyarakat (sosial) berperan penting dalam memfokuskan persepsi terhadap risiko tertentu. Individu dalam siklus sosial akan saling mempengaruhi dalam mengambil keputusan. Masyarakat membutuhkan pemahaman akan pentingnya menjaga jarak sosial tanpa merusak kekerabatan sosial. Kekerabatan yang kental menjadi modal kuat bagi masyarakat Bugis. Berbasis nilai kekerabatan inilah risiko terhadap keuangan dan kehilangan waktu dipersepsikan bisa diatasi oleh masyarakat. Meskipun terdapat ketidakpastian atas pendapatan dan pemanfaatan waktu namun modal sosial ini menjadi penguat. Eliza Meiyani (2010) mengungkapkan bahwa nilai-nilai kekerabatan sebagai sarana pembentukan kualitas individual, pemimpin dan masyarakat yang harmonis. Nilai kekerabatan ini akan berpengaruh dalam membangun kesiapsiagaan terhadap penyebaran Covid-19 dan imbauan social distancing.

\section{KESIMPULAN}

Penelitian ini menggambarkan masyarakat dalam mempersepsikan risiko terhadap adanya penyebaran virus Corona dan imbauan social distancing. Temuan pada penelitian menjadi menarik perhatian oleh pemangku kepentingan agar dapat mengembangkan kebijakan, keputusan, dan program kegiatan yang tepat sasaran. Temuan ini menggambarkan secara umum bahwa masyarakat memiliki persepsi risiko sebesar $60.2 \%$, kategori sedang. Artinya bahwa dari enam tipe persepsi risiko yang dikembangkan menunjukkan angkanya merata. Angka ini bisa dimaknai bahwa ada ketidakpastian yang dirasakan masyarakat akan konsekuensi yang bisa saja muncul. Bibit ketidakpastian atas konsekunesi ini bila dapat ditagani dengan segera akan membuat masyarakat tetap optimis dalam menghadapi pandemi Covid-19 dan imbauan social distancing. Penguatan terhadap risiko psikologis bisa dilakukan oleh Kementerian Agama melalu penyuluh agama, penguatan terhadap risiko fisik bisa dilakukan oleh Dinas Kesehatan, penguatan terhadap risiko informasi bisa dilakukan oleh Dinas Informasi dan Komunikasi, penguatan terhadap risiko pendapatan, kehilangan waktu, dan sosial dapat dilakukan secara mand iri oleh kelompok masyarakat. Penguatan tersebut harus mengedepankan sinergitas dibawah koordinasi Kepala Daerah. 


\section{DAFTAR PUSTAKA}

Arslan, Y., Geçti, F., \& Zengin, H. (2018). Examining Perceived Risk and Its Influence on Attitudes: A Study on Private Label Consumers in Turkey. Canadian Center of Science and Education, 9(4), 158-166.

Buddy, J.W. (2006). Adoption if Innovations in Library Media Program. School Librari Media Activities Monthly, 22 (8), 56-58

Clifford W. Scherer. (2003). A Social Network Contagion Theory of Risk Perception. Risk Analysis an International Jurnal. April 2003. Volume 23, Issue 2. 261-267

Cunningham, C. (2014). Religion and Spirituality as Factors That Influence Occupational Stress and Well-Being, The Role of Demographics in Occopational Stress and Well Being. Research in Occupational Stress and Well Being, Vol.12), Emerald Group Publishing Limited, PP. 135-172

Lufityanto, G., Rahapsari, S., \& Kamal, I. (2020). Identifikasi stress terhadap perubahan melalui pengukuran kognitif dan respon Hypothalamic-Pituitary-Adrenal. Jurnal Psikologi Integratif, 7(2), 77-92. doi:http://dx.doi.org/10.14421/jpsi.v7i2.1812

Hoyer, W., MacInnis, D., \& Pieters, R. (2013). Consumer behavior 6th ed. United States of America: South-Western Cengage Learning.

Maciejewski, G. (2012). The meaning of perceived risk in purchasing decisions of the Polish customers. Scientific Anuals of The "Alexander Ioan Cuza "University of Iasi, Economic Sciences, Volume LVIII, 1-24

Melissa Gunawan, Evelien Alim Sompie, Fransisca Andreani. (2017). Analisa Pengaruh Persepsi Risiko Terhadap Keputusan Pembelian di Airbnb. Jurnal Hospitality dan manajemen jasa, Vol.5, no.2, 212 - 223.

Nuning Nuraini, Kamal Khairudin, Mochamad Apri (2020). Data dan Simulasi Covid-19 dipand ang dari Pendekatan Model Matematika. Pusat Pemodelan Matematika dan Simulasi - ITP dan KK Matematika Industri dan Keuangan - FMIPA - ITB. http://eprints.itb.ac.id/119/1/COVID19\%20Corona-NN\%20KKS\%20MA\%20Final.pdf, diakses tanggal 23 Maret 2020.

Riduwan dan Engkos Achmad Kuncoro. (2011). Cara Menggunakan dan Mamaknai Path Analysis (Analisis Jalur). Bandung: Alfabeta.

Riyanti Djalante, Jonatan Lassa, Davin Setiamarga, dkk. (2020). Review and analysis of current responses to Covid-19 in Indonesia: Period of January to March 2020. Jurnal Progress in Disaster Science. Vol. 6 April 2020, 1-9 https://doi.org/10.1016/j.pdisas.2020.100091

Shiffman, L.G. \& Kanuk, L.L. (2004). Perilaku Konsumen. Edisi 7. Jakarta: Prentice Hall 
Schiffman, L.G. \& Kanuk, L.L (2010). Consumer behavior (10th ed.). USA: Prentica Hall International, Inc

Slovic, P. (2000). The Perception of Risk. The University of Michigan: Earthscan Publication.

Sugiyono. (2012). Metode Penelitian Kuantitatif Kualitatif dan R\&D. Bandung: Alfabeta.

Timothy C. Reluga. (2010). Game Theory of Social Distancing in Response to an Epidemic. PLoS Comput Biol. Vol. 6 (5). 1-9

Yeung, R. (2009). Tourist perception of food safety risk and destination choice. International Journal of Hospitality and Tourism, 2(1), 21-33.

Yan Bai, Lingsheng Yao, Tao Wei, dkk. (2020). Presumend Asymptomatic Carrier Transmission of Covid-19. Jama Research Letter, American Medical Association. Pubslished February 21, 2020 doi:10.1001/jama.2020.2565 